Available online at https://jurnal.stmikroyal.ac.id/index.php/jurdimas

\title{
KONVERGENSI MEDIA DALAM PEMASARAN PRODUK KERAJINAN MASYARAKAT DESA WISATA PARIANGAN
}

\author{
Rahmatul Husna Arsyah ${ }^{1 *}$, Astri Indah Juwita ${ }^{1}$ \\ ${ }^{1}$ Fakultas Keguruan dan Ilmu Pendidikan, Universitas Putra Indonesia 'YPTK' Padang \\ email: *rahmatulhusna_arsyah@upiyptk.ac.id
}

\begin{abstract}
Nagari Pariangan as the most beautiful tourist village in the world has a place to help the community's economy, increase local revenue (PAD). Local industrial products that have been owned by the community can become souvenirs for visiting tourists. However, in fact Nagari Pariangan does not have the media to promote it. This study aims to analyze the convergence of media in marketing the local industrial handicraft products of the community. This research approach is descriptive qualitative, with data collection methods, namely by means of observation and interviews and literature review. The results of this study reveal that Nagari Pariangan is an area with tourism potential that has become the spotlight of the world, there is a need for a media that helps the community in introducing local Nagari products in order to increase local community income. The main key to convergence is digitization, Nagari Pariangan does not yet have digital media as a forum for supporting community industrial output. Based on the 3C technology dimension (Communication, Compute and Contents), which consists of the IT Industry, Telcom Infrastructure Provides, and the Content Industry. Nagari Pariangan is considered capable of building a digitalized medium, in order to be able to make the economy of the people in areas that have tourism potential much better.
\end{abstract}

Keywords: convergence; craft produk; media

\begin{abstract}
Abstrak: Nagari Pariangan sebagai desa wisata terindah dunia memiliki wadah untuk membantu perekonomian masyarakat, menambah pendapatan asli daerah (PAD). Hasil Industri lokal yang selama ini dimiliki oleh masyarakat bisa menjadi oleh-oleh bagi wisatawan yang berkunjung. Namun, pada kenyataanya Nagari pariangan belum memiliki media dalam mempromosikannya. Penelitian ini bertujuan untuk melakukan analisis konvergensi media dalam memasarkan produk kerajinan industri lokal masyarakat. Metode penelitian ini adalah kualitatif deskriptif, dengan metode pengumpulan data yaitu dengan cara observasi dan wawancara serta kajian literatur. Hasil dari penelitian ini mengungkapkan bahwa Nagari Pariangan merupakan daerah dengan potensi wisata yang sudah menjadi sorotan dunia, dan perlu adanya sebuah media yang membantu masyarakat dalam memperkenal produk lokal nagari agar bisa menambah pendapatan masyarakat setempat. Kunci utama konvergensi adalah digitalisasi, Nagari Pariangan belum memiliki media digital sebagai wadah dalam mendukung hasil industri masyarakat. Berdasarkan dimensi teknologi 3C (Communication, Compute and Contents), yang terdiri dari IT Industry, Telcom Infrastructure Provides, serta Content Industry. Nagari Pariangan dirasa mampu untuk membangun sebuah media yang digitalisasi, agar mampu menjadikan ekonomi masyarakat di daerah yang memiliki potensi wisata jauh lebih baik.
\end{abstract}

Kata kunci: konvergensi; media; produk kerajinan 
Available online at https://jurnal.stmikroyal.ac.id/index.php/jurdimas

\section{PENDAHULUAN}

Nagari Parianagan merupakan salah satu desa terindah di dunia dari 5 negara, yang terletak di Kecamatan Pariangan Kabupaten Tanah Datar, Sumatera Barat. Nagari yang terletak di lereng Gunung Merapi ini memiliki posisi peta yaitu $-0,4576440,100,4933660$. Menurut Tambo Minangkabau Pariangan adalah nagari tertua di ranah Minang. Desa ini menempati wilayah seluas $17,92 \mathrm{~km}^{2}$ dan secara administratif berada di bawah Kecamatan Pariangan, dengan jumlah penduduk sekitar 6.479 jiwa. Lokasinya yang berada di lereng Gunung Merapi membuat udaranya tetap sejuk. Nagari ini menjadi viral semenjak munculnya informasi di salah satu TV Swasta yang menayangkan bahwa berdasarkan majalah Travel Budget terbitan New York, Nagari Pariangan layak menyandang predikat "desa terindah dunia” sejak tahun 2012.

Masyarakat nagari Pariangan selaku tuan rumah desa wisata ini, tentunya mendapatkan income tersendiri dengan adanya penobatan tersebut, terkhusus untuk kemajuan ekonomi masyarakat. Produk kerajinan yang biasanya menjadi rata-rata usaha dan penghasilan utama masyarakat Pariangan adalah berupa kerajinan tangan, seperti tenun, sulaman, dan bordiran serta batik khas Pariangan. Kerajinan semcam ini sudah lama dimiliki oleh masyarakat setempat, namun hal ini belum menjadi soroton wisatawan yang berkunjung. Berdasarkan observasi yang dilakukan terlihat bahwa masyarakat belum fokus pada pemasaran produk untuk daerah potensi wisata seperti Pariangan. Pada peringkat global, pariwisata merupakan industri penting dan penyumbang terbesar perdagangan internasional selain ekspor barang dan jasa (Bayu, 2013)
Bagi daerah industri hal ini merupakan penyokong dari Pendapatan Asli Daerah (PAD).

Kemajuan teknologi saat ini sudah dirasakan dan dimanfaatkan oleh semua kalangan masyarakat, mulai dari media sederhana sampai dengan dengan media kompleks. Berbagai kemudahan memperoleh informasi dari berbagai penjuru dapat dinikmati dalam hitungan detik. Sudah banyak pergeseran kemajuan media dari yang lama hingga ke media yang baru, diantaranya digitalisasi. Istilah digitalisasi banyak digunakan dalam teori konvergensi. (Jenkins, 2006) mengatakan, bahwa yang dimaksud dengan konvergensi yaitu $A$ word that describes technological, industrial, cultural, and social changes in the ways media circulates within our culture, yang bermakna kata yang digunakan untuk mendeskripsikan perubahan teknologi, industri, budaya, dan sosial yang bergantung pada siapa yang berbicara dan apa yang mereka bicarakan.

istilah konvergensi mengacu pada konvergensi media yaitu proses dimana media lama dan media teknologi baru dapat digunakan secara terpisah atau diperoleh bersama melalui digitalisasi. Menurut pendapat para ahli disimpulkan bahwa konvergensi media mengacu pada bentu pemikiran media tradisional, yang secara berangsur-angsur menghilang dan bergantian dengan penggunaan internet.

Konvergensi tidak hanya fokus pada teknologi. Ada lima proses yang dapat mengubah produksi dan konsumsi media, yaitu: konvergensi ekonomi, konvergensi sosial, konvergensi teknologi, konvergensi budaya, dan konvergensi global. (Jenkins, 2006) menjelaskan bahwa konvergensi media adalah aliran konten dibeberapa platform media. Dapat disimpulkan bahwa konvergensi media 
Available online at https://jurnal.stmikroyal.ac.id/index.php/jurdimas

adalah kemampuan media dalam menyampaikan berbagai bentuk konten kepada publik.

$$
\text { Untuk membantu masyarakat }
$$

nagari Pariangan dalam memasarkan produk hasil kreatifitas masyarakat, perlu adanya media sehingga informasi berupa promosi produk/kerajinan dapat diterima secara cepat oleh wisatawan yang berkunjung secara langsung ataupun tidak langsung. Observasi yang telah dilakukan menunjukkan bahwa masyarakat selama ini, hanya memasarkan produk dari mulut ke mulut, lewat toko dan ada beberapa yang dikirim keluar, Namun belum ada media teknologi khusus yang digunakan.

(Grant \& Wilkinson, 2009) berpendapat bahwa konvergensi media berdampak signifikan pada kedua teknologi tersebut, yaitu teknologi digital dan jaringan komputer. Konvergensi teknologi itu sendiri disebabkan oleh banyak hal. Fokus konvergensi teknologi adalah transformasi teknologi dari analog ke digital. Konvergensi media membawa impikasi terhadap persebaran atau distribusi pesan digital. Oleh karena itu peneliti tertarik melakukan analisis terkait konvergensi media dalam membantu pemasaran produk kerajinan masyarakat Nagari Pariangan.

\section{METODE}

Penelitian ini menggunakan metode deskriptif kualitatif. Penelitian kualitatif diberbagai tempat mengedepankan hipotesis bahwa kebenaran bersifat subjektif bagi setiap peneliti, yang bergantung pada pemahaman dan makna terdalam dari penelitian dan lingkungan (Cassell \& Symon, 2004). Metode deskriptif adalah metode untuk memeriksa keadaan sekelompok manusia, objek, kondisi, sistem pemikiran atau kategori peristiwa.

Objek penelitian yang menjadi fokus penelitian adalah Dinas UMKM dan Koperindag Tanah Datar, yang menghimpun informasi dan data terkait hasil kerajinan masyarakat Nagari Pariangan. Dengan lokasi penelitian di Nagari Pariangan Kabupaten Tanah Datar, Sumatera Barat, sebuah daerah yang menjadi desa wisata terindah dunia. Sedangkan yang terlibat sebagai informan peneliti adalah staff Dinas UMKM dan Koperindag serta Organisasi UKM Industri masyarakat.

Untuk mendukung penelitian ini diperlukan beberapa data, sehingga digunakan teknik pengumpulan data berupa studi pustaka, studi lapangan dalam bentuk observasi dan wawancara. Selanjutnya dilakukan teknik analisis data memiliki tiga proses yang berlangsung interaktif, yaitu reduksi data, analisis data, dan menarik kesimpulan.

\section{PEMBAHASAN}

Produk industri pariwisata dapat dinikmati hanya di tempat keberadaannya sehingga konsumen/wisatawan harus mendatangi/mengunjungi tempat keberadaan objek (Warpani \& Ndira, 2007). Oleh karenanya, jelas bahwa dengan adanya potensi daerah wisata mampu menambah pendapatan asli daerah (PAD) dengan menyediakan produk unggulan daerah tersebut.

Nagari pariwisata Pariangan yang sejuk dipandang mata dengan sawahsawah menghijau yang tersusun indah ini, juga memiliki bangunan Rumah Gadang Minangkabau. Ciri khas dari rumah gadang ini adalah memiliki dinding yang terbuat dari anyaman rotan, dan ukiran kayu. 
Berikut penampakan alam Nagari Pariangan yang sudah dikenal dunia sebagai desa wisata, berdasarkan sumber http://www.wonderfulminangkabau.com, dapat dilihat pada gambar 1.

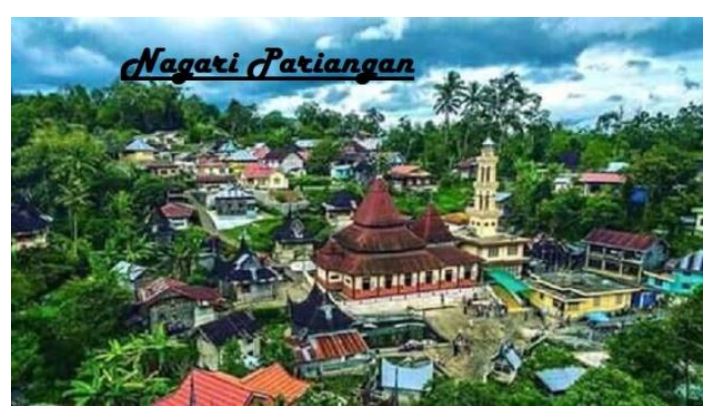

Gambar 1. Alam Nagari Pariangan

Sebagai salah satu destinasi pariwisata Sumatera Barat, ada beberapa yang menjadi potensi objek wisata di Kabupaten Tanah Datar ini.

Tabel 1. Objek Wisata Tanah Datar

\begin{tabular}{ll}
\hline No & \multicolumn{1}{c}{ Wisata Alam } \\
\hline 1 & Gunung Merapi \\
\hline 2 & Gunung Singgalang \\
\hline 3 & Puncak Pato \\
\hline 4 & Panorama Tabek Patah \\
\hline 5 & Danau Singkarak \\
\hline 6 & Lembah Anai \\
\hline 7 & Aur Sarumpun \\
\hline 8 & Wisata Sejarah dan Budaya \\
\hline 9 & Pagari Tuo Pariangan \\
\hline 10 & Baliruang Sari \\
\hline 11 & Prasasti Aditiawarman \\
\hline 12 & Batu Angkek-Angkek \\
\hline 13 & Istano Baso Pagaruyuang \\
\hline 14 & Benteng Fort Van Capellen \\
\hline 15 & Nagari Pandai Sikek \\
\hline & Wisata Bahari \\
\hline 16 & Tanjung Mutiara \\
\hline
\end{tabular}

Sumber: Dinas Pariwisata Tanah Datar 2020

\section{Produksi Industri Masyarakat Pariangan}

Pariangan terkenal sebagai destinasi wisata budaya dan salah satu industri pariwisata yang mengarah pada ekonomi kreatif berupa kerajinan tangan serperti tenun, sulaman, dan bordiran serta batik khas Pariangan. Pemerintah Kabupaten Tanah Datar, Sumatera Barat akan menyiapkan sebuah galeri batik di kawasan desa Wisata Pariangan guna menunjang produksi dan penjualan batik di daerah tersebut.

Banyak kreasi yang sudah dihasilkan oleh masyarakat dengan keterampilan tangannya. Dapat dilihat pada gambar 2.
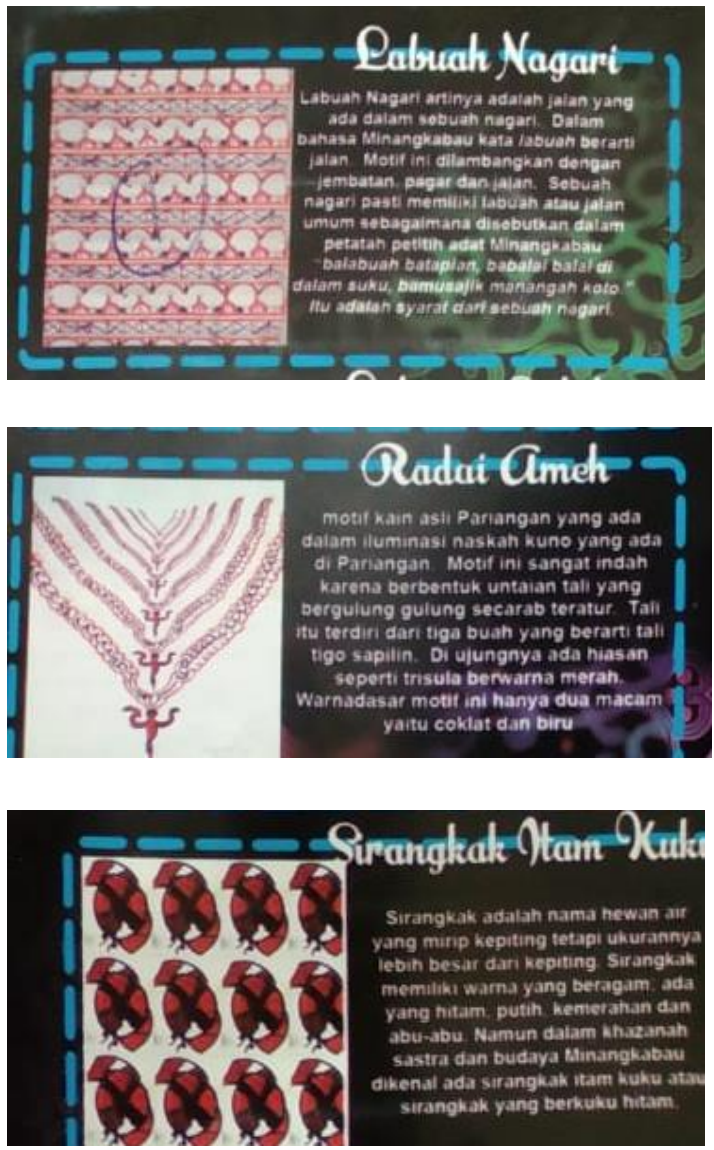

Gambar 2. Bentuk Ukiran Batik Pariangan 
Available online at https://jurnal.stmikroyal.ac.id/index.php/jurdimas

Hasil karya masyarakat selama ini masih menjadi bisnis pribadi, namun ada beberapa yang sudah di letakkan di rumah Industri. Pada dasarnya, pemerintah setempat sudah berencana dalam mendirikan sebuah Gallery yang mampu menampung semua hasil keterampilan khas Pariangan ini. Hal ini juga bertujuan agar wisatawan yang berkunjung untuk menikmati keindahan alam Pariangan, juga dapat berkunjung ke Gallery, sebagai bentuk cinderamata yang dapat dibawa pulang oleh wisatawan.

Berdasarkan info yang ada pada gambar 2 dapat diketahui, bahwa untuk nama ukiran batik Pariangan, menggunakan istilah minang, diantaranya: Labuah Nagari, Rago Bagandiang, Radai Ameh, Sirangkak Nan Kuku, Rantiang Saliguri, Roda Padati, Sijambai Ani, Kipeh Bidodari, dan lainnya. Pemakaian nama tersebut berdasarkan info dari informan, adalah untuk melestarikan nama dan istilah yang ada di ranah minang, serta memperkenalkan ranah minang ke dunia luar.

Selama ini, pemasaran produk keterampilan masyarakat ini, belum memanfaatkan yang nama nya media digitalisasi.

\section{Analisis Konvergensi Media}

Kehadiran konvergensi dengan perubahan informasi dari manual menuju digitalisasi, membuat masyarakat merasa dimudahkan dengan dapat mengakses informasinya dimana saja dan kapan saja dengan perangkat gawai atau elektronik.

Berdasarkan pengamatan yang telah dilakukan, bahwa Nagari Pariangan sebagai destinasi pariwisata belum memiliki media digital sebagai wadah dalam mendukung industri kreatif masyarakat, maka perlu adanya konvergensi media agar adanya perkembangan dan kemajuan bagi produksi dan promosi produk UMKM masyarakat Nagari Pariangan.

Teknologi 3C (Communication, Compute and Contens) mampu menjadikan ekonomi masyarakat di desa wisata lebih baik, dengan berkembangnya produk hasil industri masyarakat daerah tersebut.

Berdasarkan wawancara dengan pihak Koperindag bahwa belum semua content dapat medukung adanya konvergensi media ini. Dalam dimensi teknologi 3C, diantaranya:

\section{IT Industry}

Dalam perkembangan IT Industri di desa wisata Nagari Pariangan, terlihat belum memenuhi dimensi-dimensi yang akan mampu mendukung industri kreatif, seperti:

- Computing Hardware

- Software

- Internetworking Equipment

Berdasarkan wawancara dengan staff Koperindag bahwa dalam memasarkan hasil produksi warga dalam bentuk produk nagari Pariangan masih memanfaatkan teknologi yang manual, yaitu promosi dari segi mulut ke mulut. Belum adanya sentuhan teknologi yang bisa dimanfaatkan oleh masyarakat.

\section{Telecom Infrastructure Provides}

Dalam konvergensi media, salah satu yang perlu diperhatikan adalah penyedia infrastruktur telekomunikasi. Nagari Pariangan belum memiliki provider khusus dalam hal menangangi produk masyarakat. Melihat aspek yang ada, diantaranya:

- Public telephony networks

- Broadband cable networks

- Satelit Newtworks

- Broadcasting Networks

- Mobile Networks 
Available online at https://jurnal.stmikroyal.ac.id/index.php/jurdimas

Berdasarkan hasil wawancara, bahwa di Nagari Pariangan aspek tersebut belum bisa digunakan secara optimal dalam hal mendukung indsutri masyarakat.

\section{Content Industry}

Hal utama yang menjadi perhatian dalam konvergensi media adalah content industri, atau produk yang akan dikembangakan dalam sebuah media. Dalam penelitian ini, kerajinan tangan berupa batik dan sulaman menjadi konten yang akan dimanfaatkan.

Konvergensi media telah memungkinkan tercampurnya semua karakter media (dari analog ke digital) yang melahirkan hibridasi. Untuk memenuhi kebutuhan era teknologi saat ini, konvergesi media dapat menjadi syarat yang diperlukan bagi banyak pengusaha lokal. Secara garis besar dapat dikatakan bahwa industri berperan dalam menyediakan teknologi yang akan digunakan untuk memberikan pelayanan dan infrastruktur.

Saat ini hampir semua bidang kehidupan terkait langsung dengan TIK, yaitu perkembangan transaksi ekonomi melalui e-commerce atau perkembangan trend belanja online dalam bentuk yang sederhana.

\section{SIMPULAN}

Hasil penelitian menyimpulkan bahwa keputusan untuk melakukan konvergensi media merupakan satu langkah lebih maju daripada media yang ingin terus eksis dan berjuang memperbaiki pelayanan kepada masyarakat. Strategi 3C (Communication, Compute, dan Contents) menjadi salah satu alternative strategi untuk mentransformasikan diri menuju konvergensi, belum secara maksismal dimiliki oleh pemerintahan Nagari Pariangan. Konvergensi media akan membantu masyarakat dalam mengembangkan hasil produk kerajinan masyarakat sehingga dikenal oleh wisatawan.

\section{UCAPAN TERIMA KASIH}

Ucapan terima kasih di sampaikan kepada Universitas Putra Indonesia "YPTK" Padang, yang telah mendanai hibah penelitian Yayasan. Terimakasih kepada pemerintahan Tanah Datar, Nagari Pariangan yang telah bersedia bekerjasama dalam menganalisis dan memberian data demi kemajuan strategi promosi dengan konvergensi media.

\section{DAFTAR PUSTAKA}

Bayu S. (2013). Pengaruh Atribut Produk Wisata Tirta Terhadap Keputusan Berkunjung di Water Park Bojongsari Indramayu. Universitas Putra Indonesia.

Cassell, C \& Symon, G. (2004). Essential Guide to Qualitative Methods in Organizational Research.

Grant, A. E., \& Wilkinson J.S. (2009). Un-derstanding Media Convergence: The State of the Field. New York: Oxford University Press.

Jenkins, H. (2006). Convergence Culture: Where Old and New Media Collide. New York: New York University Press. Kaplan, Andreas M.; Michael Haenlein.

Warpani, P, S.,„\& Ndira P. (2007). Pariwisata dalam Ta-ta Ruang Wilayah. Institut Teknologi Bandung. 